\title{
Cooling effect potential from liquefied petroleum gas flow in the fuel line of vehicle
}

\author{
M. Setiyo ${ }^{1 *}$, D.R.B. Syaka ${ }^{2}$, B. Waluyo ${ }^{1}$, N. Hamidi ${ }^{3}$, and B.F.T. Kiono ${ }^{4}$ \\ ${ }^{1}$ Department of Automotive Engineering, Universitas Muhammadiyah Magelang \\ Jl. Bambang Soegeng, Mertoyudan, Magelang 56172, Indonesia \\ ${ }^{2}$ Department of Mechanical Engineering, State University of Jakarta \\ Jl. Rawamangun Muka, Jakarta 13220, Indonesia \\ ${ }^{3}$ Department of Mechanical Engineering, University of Brawijaya \\ Jl. MT. Haryono 165 Malang 65145, Indonesia \\ ${ }^{4}$ Department of Mechanical Engineering, Diponegoro University \\ J1.Prof.H.Soedarto Semarang 50275, Indonesia \\ *Email: setiyo.muji@ummgl.ac.id
}

\begin{abstract}
This paper presents a simulation of the potential cooling effect that can be harvested from the Liquefied Petroleum Gas (LPG) phase change process on the fuel line before being supplied to the combustion chamber. The composition of LPG used was obtained from the average test result of the samples taken periodically in the fuel line with a special gas syringe which were then injected into Gas Chromatography-Mass Spectrometry (GCMS). Effect of fluctuations of LPG composition was also analysed on the energy delivery to the combustion chamber. Furthermore, simulation results showed that the potential cooling that may be harvested from the LPG fuel system on a $2000 \mathrm{~cm}^{3}$ engine was 1.4 $\mathrm{kW}$ in the eco-driving mode to be used as a cabin cooler. For a small passenger car that has a cooling load of $3.5 \mathrm{~kW}$, this means the cooling effect from the fuel system is capable of contributing $40 \%$ to the cooling load. In conclusion, this potential is very promising and can be applied to countries that not do have the winter experience.
\end{abstract}

Keywords: LPG composition; combustion energy, potential cooling effect.

\section{INTRODUCTION}

The transport sector holds an important role in a country's economy. A sustainable transportation system is everyone's expectations to have a good access to the economic opportunities and mobility needed to improve their lives [1, 2]. However, with the increasing number of vehicles on the roads, it raises the issue of pollution and concerns about the energy supply in every country [3-5]. Gasoline and diesel vehicles are clearly not the right choices in the future because they will be faced with supply and availability, government burden due to subsidies, and environmental issues especially in big cities [6]. In the last decade, as an intention to reduce the use of conventional fuels (gasoline and diesel), research activity for a mixture of fossil and alternative fuels has shown progressive results [7-11], but large-scale applications on older vehicles that are not designed for mixed fuel applications still leave much work. On the other hand, biofuel production and applications will challenge the availability of land for crop production [12]. In Indonesia, applying old vehicle retirement programmes and switching from 
conventional fuels to $\mathrm{CNG}$ may be a long-term solution to cut subsidy costs and reduce $\mathrm{CO}_{2}$ emissions $[6,13,14]$. Nevertheless, it will require an enormous investment to build a reliable $\mathrm{CNG}$ infrastructure and need a government policy in the form of incentives for vehicle retirement programs. The investment of electric vehicles (EVs) and fuel cells (FCVs) as green cars has also not been feasible for now due to limited mileage and high cost of ownership [15]. Therefore, switching to LPG becomes a viable option for the medium term, at least in the next 15-20 years [16-18]. A techno-economic review of conversion costs has also been made and shows promising results when compared to the current conventional fuel prices available without price subsidies by the government [19].

From the first time LPG was applied as vehicle fuel (the 1900s) to now, many researchers have been involved in the performance study of the gasoline engine driven by LPG, especially in the terms of emission and power improvement. Almost all studies reported positive results that the emissions from LPG engines are lower than those fuelled by gasoline [19-22]. On the contrary, many researchers reported the negative effect on low output power even in different quantities as presented Masi and Gobbato [20]. They concluded that the probability of power loss in LPG engines is lower volumetric efficiency due to the intake of air replaced by gas fuel. In other studies, various modifications of engine components and adjustment of ignition timing can reduce power losses but are generally only obtained under partial load conditions [21-24]. As it is known that as long as LPG is supplied to the intake manifold in the vapour phase, it will take up a larger volume than gasoline for the same energy content. In the study by Price et al. [24] an LPG evaporator was investigated in detail to determine the evaporative heat requirements supplied from a portion of the engine coolant stream. The results of this study confirmed that the power loss of LPG engine was due to volumetric efficiency factor. Gaseous LPG coming out of the evaporator reached $60^{\circ} \mathrm{C}$ which means its density decreased. However, the study by Price et al. provided another interesting fact. One the one side, a disadvantage occurred because the LPG vapour was too hot; on the other hand, there was a temperature drop in the coolant that was across the evaporator. The decrease in engine coolant temperature reached $7^{\circ} \mathrm{C}$ on a coolant flow of $0.6 \mathrm{~kg} / \mathrm{s}$. In the previous study, through a numerical simulation, a $2000 \mathrm{~cm}^{3}$ LPG-fuelled engine was able to produce a cooling effect of more than $1 \mathrm{~kW}$ at $3000 \mathrm{rpm}$ [25]. In this study, various mixtures of LPG (propane to butane) were simulated. Potential cooling effects that can be harvested were calculated based on the differences in LPG enthalpy before and after the evaporator/LPG vaporiser was obtained from REFPROP-NIST, with LPG mass flow rates calculation based on the Masi and Gobato's studies [19]. Since LPG was able to evaporate at temperatures below $0^{\circ} \mathrm{C}$, the heat supply from the engine coolant can be replaced with ambient air to produce a cooling effect. However, this numerical study has not considered the real condition. It is almost impossible to harvest the cooling effect of an original evaporator without adding an auxiliary evaporator because the heat transfer area is too small.

The composition of LPG in previous studies was also not obtained from the actual test results. As it is known, LPG for the automotive market is not limited by composition but limited by their properties, including energy content, resistance to knocking, and volatility [26]. In this idea, LPG from the tank is functioning as a refrigerant before it is sent to the engine as fuel. In this case, the composition of LPG is very influential because it is associated with changes in the enthalpy of evaporation. In Indonesia, the composition of LPG for the automotive sector (called LGV) has been determined by the government but not set in a definite composition, only specified by minimum $\mathrm{C}_{3}$ and $\mathrm{C}_{4}$ boundaries to be met in the mixture. In fact, the measurement of the composition of LPG conducted by 
[27] on four refineries in Indonesia showed different results from one to another [28]. Therefore, this article presents the results of an investigation of the composition of LPG in the fuel line during operation, from full tank to empty. Furthermore, the results of these investigations were used to predict energy delivery to the engine and the potential cooling effect available.

\section{METHODS AND MATERIALS}

\section{Investigation of LPG Composition}

In this study, LPG tanks were filled to the full level $(20 \mathrm{~kg})$ in an LGV Station. Then, the tank was placed on a digital balance sheet and left for one day. LPG tanks with multivalve, shut-off valve, expansion valve, evaporator, and flow meter were assembled as shown in Figure 1. Three thermocouples $\left(\mathrm{T}_{1}, \mathrm{~T}_{2}, \mathrm{~T}_{3}\right)$ and two pressure transducer $\left(\mathrm{P}_{1}, \mathrm{P}_{2}\right)$ were placed at each state point where the LPG property will be observed. The sample LPG was taken during the emptying process using a special gas syringe every $2 \mathrm{~kg}$ of weight loss at an LPG flowrate of $1.4 \mathrm{~g} / \mathrm{s}$. Furthermore, the sample was analysed by TQ8040 series of Gas Chromatography-Mass Spectrometry (GC-MS).

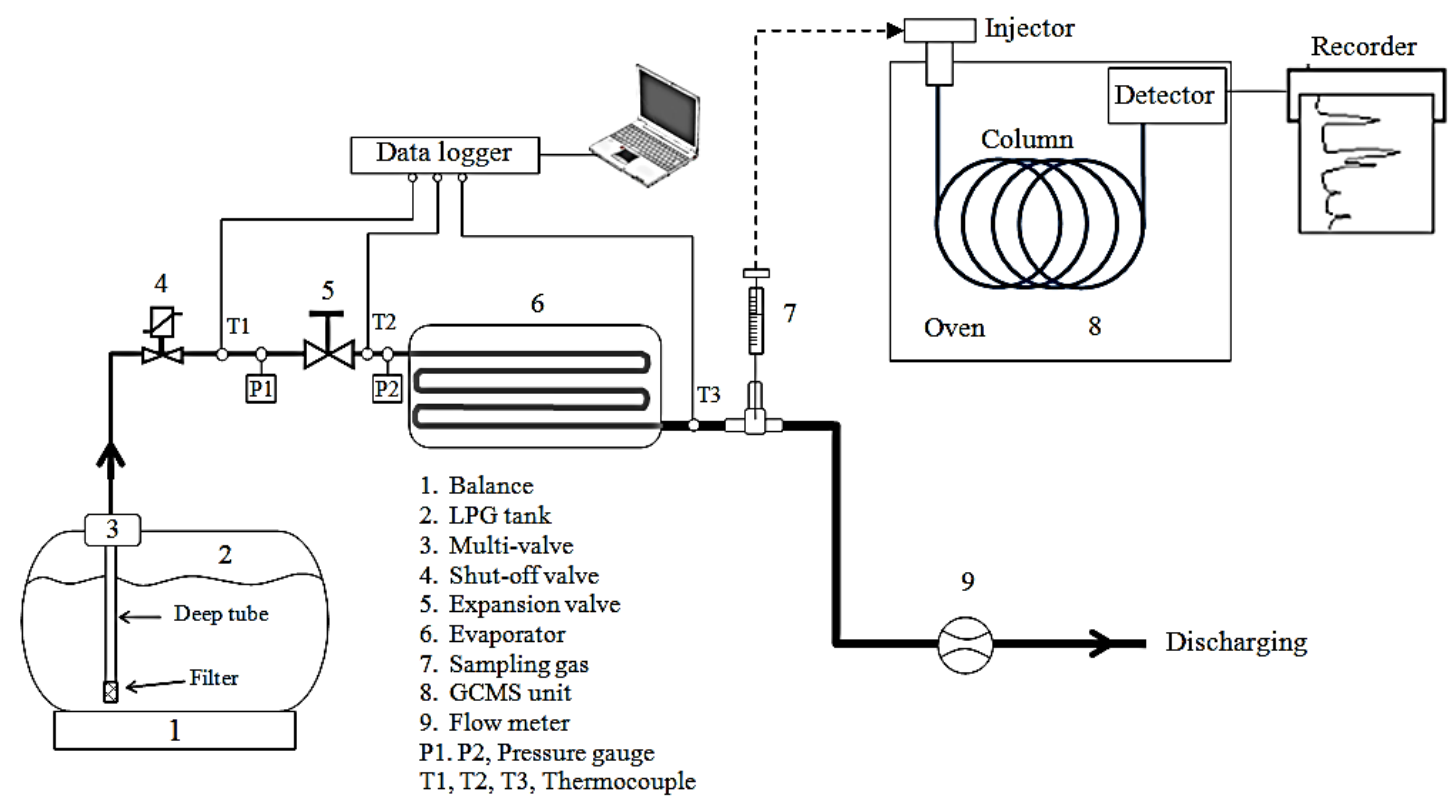

Figure 1. Experimental set up and apparatus for monitoring LPG composition.

\section{Temperature and Pressure Measurements}

During the test, temperature and pressure were continuously recorded to monitor the physical property of LPG. LPG temperature was recorded by PT-100 thermocouples, and then fed to the multi-channel modular temperature controller TM4-N2RB series. Furthermore, the temperatures data were processed and displayed on a personal computer through the DAQ master software, also in Present Value (PV). The measurements accuracy of temperature was $\mathrm{PV} \pm 0.5 \%$ or $\pm 1^{\circ} \mathrm{C}$. Meanwhile, the pressure of LPG (in gauge) before and after the expansion valve was recorded by PSAN pressure transducers in Present Value (PV). The measurement accuracy of pressure was $\mathrm{PV} \pm 0.5 \%$ F.S at $0^{\circ} \mathrm{C}$ to $50^{\circ} \mathrm{C}$ and $\mathrm{PV} \pm 1 \%$ F.S at $-10^{\circ} \mathrm{C}$ to $0^{\circ} \mathrm{C}$. The test results of the $\mathrm{LPG}$ composition were then analysed to determine the effect on the energy delivery to the combustion chamber 
and to estimate the potential cooling effect available. Energy delivery was calculated by the Wobbe Index and Potential Cooling effect was calculated numerically using the Cycle-tempo software.

\section{RESULTS AND DISCUSSION}

\section{LPG Compisitions}

The results of the LPG compositions test using GC-MS are presented in Figure 1 as follows and test data are presented in Appendix 1.

\section{Effect on Combustion Energy}

From Figure 2, it can be seen that there is a fluctuation of the percentage of propane to 2methyl butane in the fuel line during the LPG tank emptying. Because propane and 2methyl butane have different energy content (Higher Heating Value, HHV), the fluctuations of the composition needed to be analysed in relation to the energy delivery to the combustion chamber. HHV propane was $50.33 \mathrm{~kJ} / \mathrm{kg}$ and HHV 2-methyl butane was $48.57 \mathrm{~kJ} / \mathrm{kg}$ [29]. Therefore, the fluctuation of the composition was evaluated using the Wobbe Index $\left(I_{W}=H H V / \sqrt{S G}\right)$, where, $I_{W}$ is Wobbe index, $H H V$ is higher heating value of fuel, and $S G$ is specific gravity. $I_{W}$ is an indicator of interchangeability fuel and it was used to compare the combustion energy output of different gas fuel compositions. If two types of fuel have identical $I_{W}$, the combustion energy will also be identical, by the same pressure settings in the LPG converter kits.

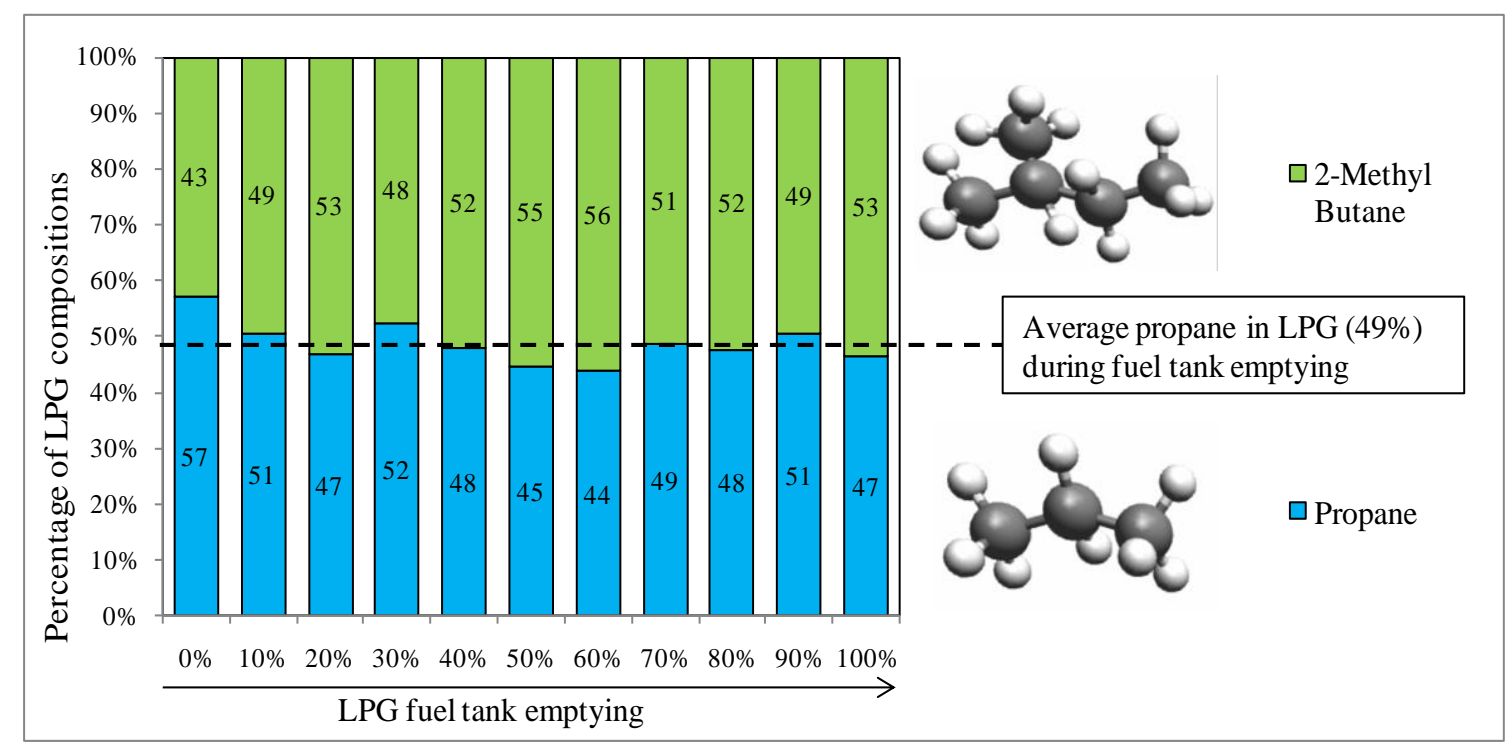

Figure 2. LPG composition during fuel tank emptying at $1.4 \mathrm{~g} / \mathrm{s}$

By the $S G$ of propane and butane 2-methyl of 0.45 and 0.62 , the $I_{W}$ of propane and butane 2-methyl was 71.53 and 61.68, repectively. From Figure 2, it can be seen that the change of propane to butane 2-methyl during the LPG tank emptying is $43.78 \%$ to $57.05 \%$ or $I_{W}=65.99$ to $I_{W}=67.29$. This means that the largest $I_{W}$ to smallest $I_{W}$ is only $2.32 \%[30] . I_{W}$ of less than 5\% indicated that the change in the composition of propane to butane-2 methyl did not have a significant effect on combustion energy in SI engine $[31,32]$. However, the difference in LPG composition test results may be smaller due to the uncertainty of the test by GC-MS [33-37], which indicated that the percentage of 
propane to 2-methyl butane in the fuel line was unchanged. This is consistent with the result of the unchanged temperature drop during LPG tank emptying measured on the expansion valve as shown in Figure. 3.

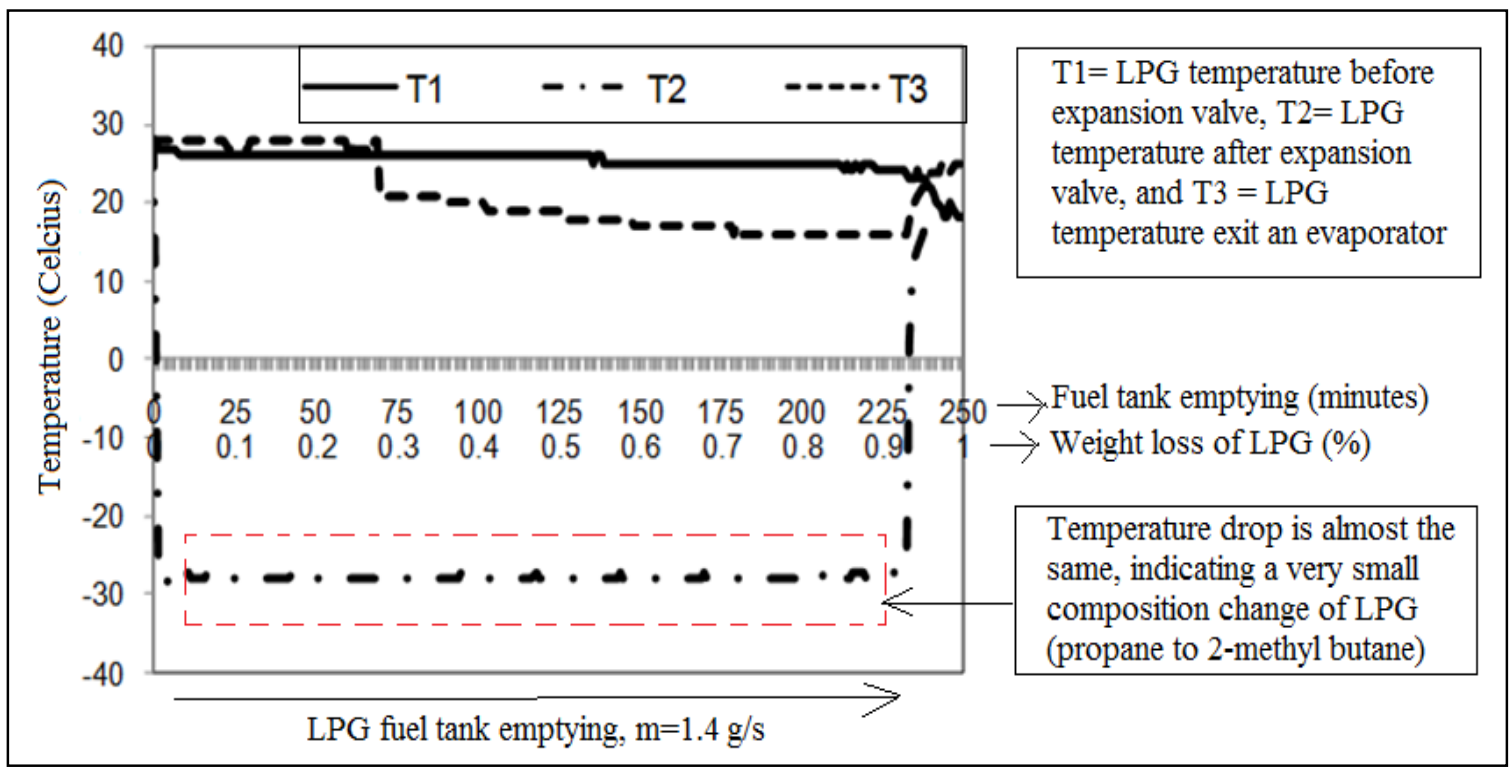

Figure 3. Validation LPG composition change by temperature drop after expansion valve $\left(\mathrm{P}_{\mathrm{T} 1}=0.6 \mathrm{MPa}\right.$ and $\left.\mathrm{P}_{\mathrm{T} 2}=0.03 \mathrm{MPa}\right)$.

\section{Effect on Potential Cooling Effect}

One of the advantages of LPG fuel is the presence of potential cooling effects when phase changes occur from liquid to vapour. Since LPG vapour temperature is much lower than $0^{\circ} \mathrm{C}$ as shown in Figure 3, it provides an opportunity to be evaporated with ambient air, resulting in a cooling effect to be supplied to the cabin with the concept as shown in Figure 4 as follows [38].

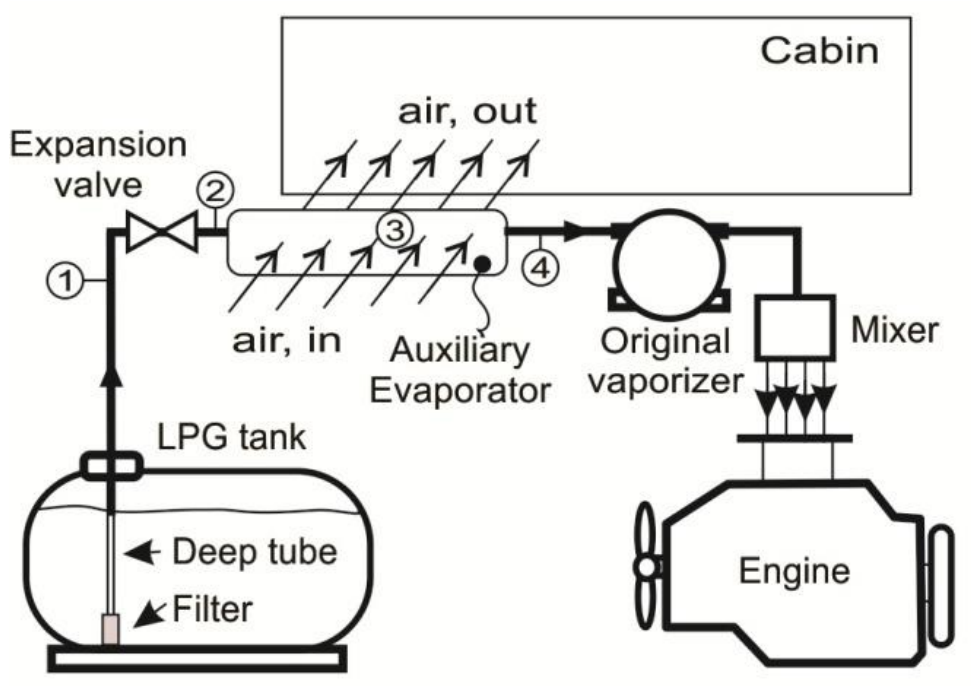

Figure 4. The concept of harvesting cooling effect on LPG vehicle: (1) LPG before expansion valve, (2) LPG after expansion valve, (3) heat exchange process, and (4) LPG exit evaporator. 


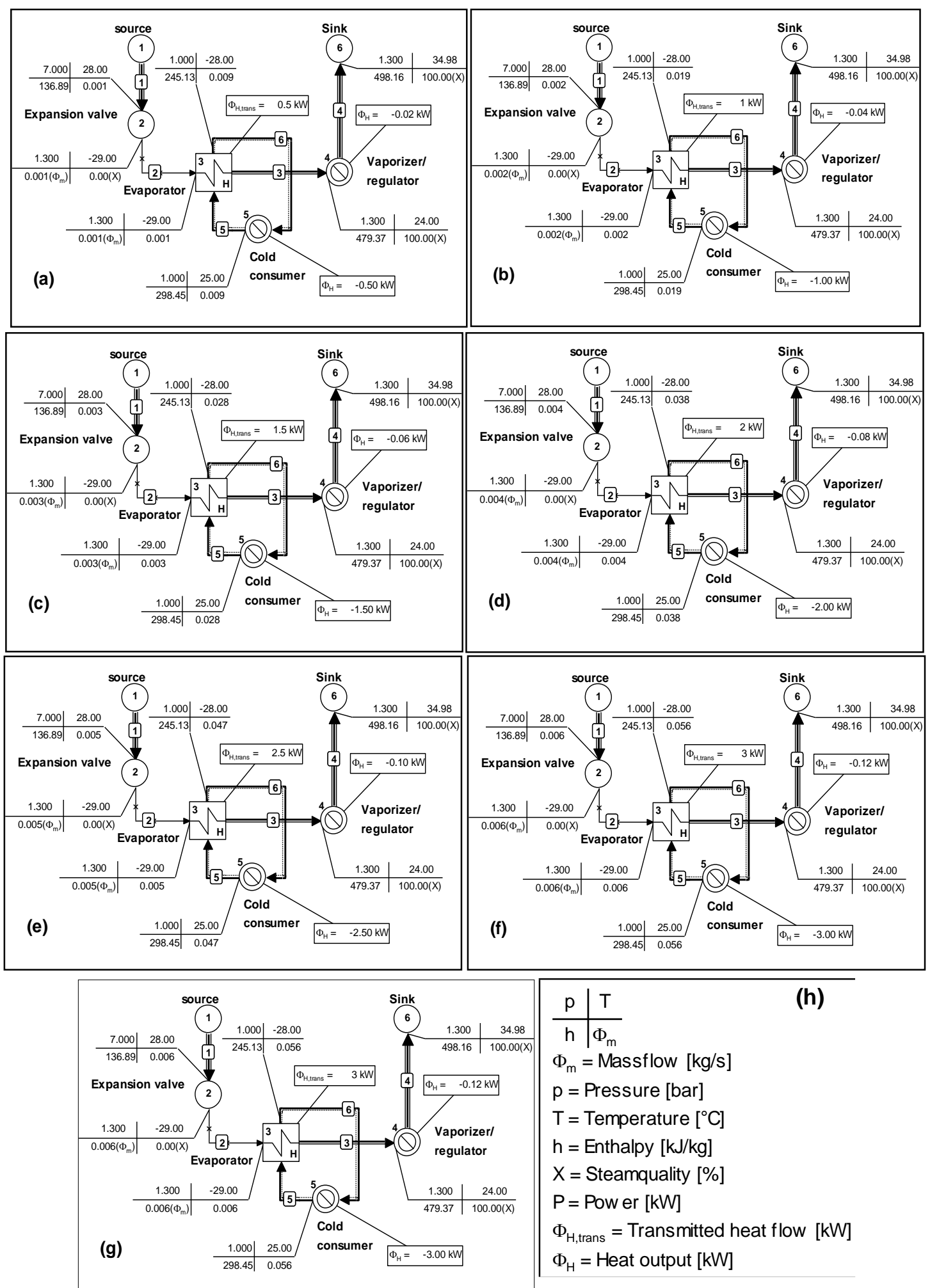

Figure 5. Simulation resuts in Cycle-tempo: (a) to (g) are the cooling load from $0.5 \mathrm{~kW}$ to $3.5 \mathrm{~kW}$ and $(\mathrm{h})$ is parameter

Furthermore, the cooling effect potential was calculated by the Cycle-tempo software, where the composition of LPG was obtained from the GC-MS test results (49\% propane and 51\% 2-methyl butane) and its properties were obtained from Figure 3. By 
assuming that the cabin cooling load of a small passenger car was from 0.5 to $3.5 \mathrm{~kW}$ [39, 40], the results of potential cooling effect from evaporator are presented in Figure 5 and then sumarised in Table 1.

Table 1. Result of simulation.

\begin{tabular}{lcc}
\hline $\begin{array}{c}\text { Properties and spesific state } \\
\text { point }\end{array}$ & $\begin{array}{c}\text { Determined cooling load, equal } \\
\text { to cooling effect }(\mathrm{kW})\end{array}$ & $\begin{array}{c}\text { LPG flow rate } \\
\text { required }(\mathrm{g} / \mathrm{s})\end{array}$ \\
\hline 1. LPG $(49 \%$ propane and 51\% & 0.5 & 1 \\
2-methyl butane; & 1.0 & 2 \\
2. LPG in fuel tank $(\mathrm{P}: 7$ & 1.5 & 3 \\
Bar_g), T:28 $\mathrm{C})$ & 2.0 & 4 \\
3. LPG entering evaporator & 2.5 & 5 \\
(P:1.3 Bar_g, T: -29 $\mathrm{C})$ & 3.0 & 6 \\
4. LPG exit evaporator $(\mathrm{P}: 1.3$ & 3.5 & 7 \\
Bar_g, T: $\left.24^{\circ} \mathrm{C}\right)$ & & \\
\hline
\end{tabular}

From Figure 5, the LPG flow rates have been obtained to produce a cooling effect of 0.5 to $3.5 \mathrm{~kW}$. Referring to a study conducted by Masi and Gobbato [18], a $2000 \mathrm{~cm}^{3}$ engine tested at 1000 to $6000 \mathrm{rpm}$ requires almost linear LPG consumption of 1.1 to 6.7 $\mathrm{g} / \mathrm{s}$, yielding the equation of $y=-0.2+1.11 x$, where $y$ is the LPG consumption $(\mathrm{g} / \mathrm{s})$ and $x$ is the engine rotation (rpm). According to this study, a $2000 \mathrm{~cm}^{3}$ engine was capable of generating a potential cooling effect of $3.35 \mathrm{~kW}$ at $6000 \mathrm{rpm}$. However, it is impossible for a car to be driven with a high-speed engine for a long time. A study conducted by Berry [41] noted that cars are generally driven by engine speeds below $2500 \mathrm{rpm}$ to obtain an eco-driving mode, meaning that a $2000 \mathrm{~cm} 3$ car is equivalent to the LPG consumption of $2.8 \mathrm{~g} / \mathrm{s}$. Taking into account the data from Table 1,an LPG flow rate of $2.8 \mathrm{~g} / \mathrm{s}$ will produce a potential cooling effect that can be harvested from the LPG fuel line at $1.4 \mathrm{~kW}$. If the maximum cooling load for a small passenger car is $3.5 \mathrm{~kW}$, the cooling effect contribution from LPG stream in the fuel line to the cooling load is about $40 \%$ at ecodriving mode. If the $40 \%$ contribution can be fully utilised, the cooling effect obtained from the LPG fuel flow in the fuel line is greater than the over-consumption of fuel due to the operation of the vapour compression air conditioning system. For comparison, based on the results of the Centre for Energy Studies (CENERG) and the French Energy Agency (ADEME) studies, the over-consumption of fuel due to the air conditioning system is between 16 and $31 \%$ for the extra-urban cycle and urban cycles as reported by [42]. Thus, the lower combustion efficiency of the LPG-fuelled engine compared to gasoline engine can be covered by harvesting cooling effects on the fuel line for cabin cooling, resulting in increased total efficiency.

\section{CONCLUSIONS}

The results of the LPG composition test during the tank emptying showed that the change in propane composition to 2-methyl butane was insignificant. This means that there was no effect on energy content transferred to the combustion chamber. Furthermore, the simulation results related to the potential cooling effect that can be harvested from LPG phase changes in the fuel line showed promising results. A $2000 \mathrm{~cm}^{3}$ engine operated in eco-driving was capable of producing the cooling effect potential of $0.5-1.4 \mathrm{~kW}$, 
depending on ethe ngine speed. If this potential can be fully utilised, it will contribute about $40 \%$ to the cooling load on small passenger cars with a cooling load of $3.5 \mathrm{~kW}$.

\section{ACKNOWLEDGEMENTS}

The authors would like to thank to Universitas Muhammadiyah Magelang, Indonesia for financial assistance and laboratory facilities

\section{REFERENCES}

[1] Zhang M, Li H, Zhou M, Mu H. Decomposition analysis of energy consumption in Chinese transportation sector. Applied Energy. 2011;88:2279-85.

[2] Ramasamy D, Kadirgama K, Amirruddin A, Taib M. A Vehicle body drag analysis using computational fluid dynamics. National Conference in Mechanical Engineering Research and Postgraduate Students (1st NNCMER 2010)2010. p. 342-53.

[3] Ediger VŞ, Çamdalı Ü. Energy and exergy efficiencies in Turkish transportation sector, 1988-2004. Energy Policy. 2007;35:1238-44.

[4] Ramasamy D, Kadirgama K, Noor M, Rahman M. Experiments on Dissimilar Valve Lift (DVL) for Turbulence Increment on a Bi-Fuel Compressed Natural Gas (CNG) Engine. Defect and Diffusion Forum: Trans Tech Publications; 2017. p. 19-28.

[5] Ramasamy D, Goh C, Kadirgama K, Benedict F, Noor M, Najafi G, et al. Engine performance, exhaust emission and combustion analysis of a 4-stroke spark ignited engine using dual fuel injection. Fuel. 2017;207:719-28.

[6] Widyaparaga A, Sopha BM, Budiman A, Muthohar I, Setiawan IC, Lindasista A, et al. Scenarios analysis of energy mix for road transportation sector in Indonesia. Renewable and Sustainable Energy Reviews. 2017;70:13-23.

[7] Mohanamurugan S, Sendilvelan S. Emission and combustion characteristics of different fuel In A HCCI engine. International Journal of Automotive and Mechanical Engineering. 2011;3:279-92.

[8] Kapilan N, Ashok Babu T, Reddy R. Improvement of performance of dual fuel engine operated at part load. International Journal of Automotive and Mechanical Engineering. 2010;2:200-10.

[9] Nayak S, Mishra P. Emission from a dual fuel operated diesel engine fuelled with Calophyllum Inophyllum biodiesel and producer gas. International Journal of Automotive \& Mechanical Engineering. 2017;14.

[10] Mahgoub BK, Sulaiman S, Karim ZA. Performance study of imitated syngas in a dual-fuel compression ignition diesel engine. International Journal of Automotive and Mechanical Engineering. 2015;11:2282.

[11] Waluyo B, Wardana I, Yuliati L, Sasongko MN. The role of molecule cluster on the azeotrope and boiling points of isooctane-ethanol blend. Fuel. 2018;215:17886.

[12] Association WL. Autogas incentive policies, 2015 update. Neuilly-sur-Seine; 2015.

[13] Ramasamy D, Zainal Z, Kadirgama K, Briggs HW-G. Effect of dissimilar valve lift on a bi-fuel CNG engine operation. Energy. 2016;112:509-19. 
[14] Ramasamy D, Noor M, Kadirgama K, Rahman M, Horizon W. Analysis of Modifications on a Spark Ignition Engine for Operation with Natural Gas. MATEC Web of Conferences: EDP Sciences; 2016. p. 00031.

[15] Messagie M, Lebeau K, Coosemans T, Macharis C, van Mierlo J. Environmental and financial evaluation of passenger vehicle technologies in Belgium. Sustainability. 2013;5:5020-33.

[16] Mahendra M, Muharam Y, Kartohardjono S, Giffari F. Modeling of LGV supply chain system for land transportation sector. Procedia Chemistry. 2014;9:284-94.

[17] Mahendra M, Kartohardjono S, Muharam Y. Implementation application of alternative fuel for land transportation sector in Indonesia based on other countries experience. Journal of Energy and Power Engineering. 2013;7:524.

[18] Ramasamy D, Mahendran S, Mohamed Z, Bakar R. Evaluation Of A Two Stroke Compressed Natural Gas Mixer Design By Simulation And Experimental Techniques. 2010.

[19] Setiyo M, Waluyo B, Husni M, Karmiadji DW. Characteristics of 1500 cc LPG fueled engine at various of mixer venturi area applied on tesla A-100 LPG vaporizer. Jurnal Teknologi. 2016;78:43-9.

[20] Masi M, Gobbato P. Measure of the volumetric efficiency and evaporator device performance for a liquefied petroleum gas spark ignition engine. Energy Conversion and Management. 2012;60:18-27.

[21] Erkus B, Surmen A, Karamangil MI, Arslan R, Kaplan C. The effect of ignition timing on performance of LPG injected SI engine. Energy Education Science and Technology Part a-Energy Science and Research. 2012;28:1199-206.

[22] Erkuş B, Karamangil MI, Sürmen A. Enhancing the heavy load performance of a gasoline engine converted for LPG use by modifying the ignition timings. Applied Thermal Engineering. 2015;85:188-94.

[23] Setiyo M, Waluyo B, Husni M. Performance of gasoline/LPG bi-fuel engine of manifold absolute pressure sensor (MAPS) variations feedback: Petra Christian University; 2016.

[24] Price P, Guo S, Hirschmann M. Performance of an evaporator for a LPG powered vehicle. Applied Thermal Engineering. 2004;24:1179-94.

[25] Setiyo M, Soeparman S, Hamidi N, Wahyudi S, Hanafi M. Numerical study on cooling effect potential from vaporizer device of LPG vehicle. Journal of Engineering Science and Technology. 2017;12:1766-79.

[26] Setiyo M, Waluyo B, Purnomo BC, Munahar S, Setiawan IC, Karmiadji DW. Studi Numerik: Efek Perubahan Komposisi LPG terhadap Energy Delivery pada Spark Ignition (SI) Engine. URECOL. 2017:17-20.

[27] Rosmayati L. Hydrocarbon Composition and Physical-Chemical Properties Assessment of LPG for Household. Publication Paper of Oil And Gas. 2012;46:69-77.

[28] Demirel Y. Energy: production, conversion, storage, conservation, and coupling: Springer Science \& Business Media; 2012.

[29] Setiyo M, Soeparman S, Hamidi N, Wahyudi S. Characteristic of LPG Compositions in the Fuel Line during Discharging Process. International Journal of Technology. 2017;8:114-23.

[30] Sinor J. Technical evaluation and assessment of CNG/LPG bi-fuel and flex-fuel vehicle viability. National Renewable Energy Lab., Golden, CO (United States); Sinor (JE) Consultants, Inc., Niwot, CO (United States); 1994.

[31] Union I. Petroleum B. guidebook to gas interchangeability and gas quality. 2011. 
[32] Barwick VJ. Sources of uncertainty in gas chromatography and high-performance liquid chromatography. Journal of Chromatography A. 1999;849:13-33.

[33] Zeng H, Zou F, Lehne E, Zuo JY, Zhang D. Gas chromatograph applications in petroleum hydrocarbon fluids. Advanced Gas Chromatography-Progress in Agricultural, Biomedical and Industrial Applications: InTech; 2012.

[34] Štěpán R, Hajšlová J, Kocourek V, Tichá J. Uncertainties of gas chromatographic measurement of troublesome pesticide residues in apples employing conventional and mass spectrometric detectors. Analytica Chimica Acta. 2004;520:245-55.

[35] Saari E. Towards minimizing measurement uncertainty in total petroleum hydrocarbon determination by GC-FID. Acta Univ Oul A. 2009;544.

[36] I. Altieri SB, J. Bebić, M. Belli, E. A. di Meane, G. Horvat, N. L. Lazić, S. Marinčić, M. Mehović, M. Memić, A. Menditto, T. M. Šarac, M. Patriarca, G. Pistone, M. Sega, A. Semeraro, M. Simonič, and B. Tepuš. Practical Examples on Measurement Uncertainty and Validation. Institute for Reference Materials and Measurements. 2011;2nd ed. .

[37] Setiyo M, Soeparman S, Hamidi N, Wahyudi S. Cooling effect characteristics of a $1 / 2$ cycle refrigeration system on an LPG fuel system. International Journal of Refrigeration. 2017;82:227-37.

[38] Bhatti MS. Riding in comfort: part II. Ashrae Journal. 1999;41:44.

[39] Fayazbakhsh MA, Bahrami M. Comprehensive modeling of vehicle air conditioning loads using heat balance method. SAE Technical Paper; 2013.

[40] Johnson VH. Fuel used for vehicle air conditioning: a state-by-state thermal comfort-based approach. SAE Technical Paper; 2002.

[41] Berry IM. The effects of driving style and vehicle performance on the real-world fuel consumption of US light-duty vehicles: Massachusetts Institute of Technology; 2010.

[42] Benouali J, Clodic D, Mola S, Presti GL, Magini M, Malvicino C, et al. Fuel consumption of Mobile air conditioning-Method of testing and results. The Earth Technology Forum2003. p. 1-10. 
Appendix 1. LPG compositions during fuel tank emptying taken from GC-MS.

\begin{tabular}{|c|c|c|c|c|c|c|}
\hline $\begin{array}{c}\text { Mass } \\
\text { discharge }\end{array}$ & Peak & R. Time & Area & Area $(\%)$ & Height & Name \\
\hline \multirow[t]{3}{*}{$0 \%$} & 1 & 1.267 & 69551657 & 57.05 & 32625517 & Propane (CAS) \\
\hline & 2 & 1.298 & 52299212 & 42.90 & 25071666 & Butane, 2-methyl- (CAS) \\
\hline & 3 & 1.398 & 65612 & 0.05 & 41762 & Butane, 2-methyl- (CAS) \\
\hline \multirow[t]{3}{*}{$10 \%$} & 1 & 1.238 & 85531696 & 50.70 & 37277932 & Propane (CAS) \\
\hline & 2 & 1.269 & 82981259 & 49.19 & 35672376 & Butane, 2-methyl- (CAS) \\
\hline & 3 & 1.368 & 193634 & 0.11 & 130253 & Butane, 2-methyl-(CAS) \\
\hline \multirow[t]{3}{*}{$20 \%$} & 1 & 1.269 & 77961730 & 46.92 & 37349956 & Propane (CAS) \\
\hline & 2 & 1.318 & 88003242 & 52.97 & 38180655 & Butane, 2-methyl- (CAS) \\
\hline & 3 & 1.400 & 177028 & 0.11 & 126825 & Butane, 2-methyl- (CAS) \\
\hline \multirow[t]{3}{*}{$30 \%$} & 1 & 1.248 & 79658424 & 52.41 & 38798241 & Propane (CAS) \\
\hline & 2 & 1.276 & 72229777 & 47.52 & 32020400 & Butane, 2-methyl- (CAS) \\
\hline & 3 & 1.376 & 98434 & 0.06 & 79512 & Butane, 2-methyl- (CAS) \\
\hline \multirow[t]{3}{*}{$40 \%$} & 1 & 1.262 & 64921277 & 47.82 & 32580393 & Propane (CAS) \\
\hline & 2 & 1.290 & 70737212 & 52.10 & 28798487 & Butane, 2-methyl- (CAS) \\
\hline & 3 & 1.390 & 105399 & 0.08 & 77373 & Butane, 2-methyl- (CAS) \\
\hline \multirow[t]{3}{*}{$50 \%$} & 1 & 1.240 & 56348706 & 44.79 & 32814042 & Propane (CAS) \\
\hline & 2 & 1.268 & 69365413 & 55.13 & 27836513 & Butane, 2-methyl- (CAS) \\
\hline & 3 & 1.369 & 98424 & 0.08 & 82856 & Butane, 2-methyl- (CAS) \\
\hline \multirow[t]{3}{*}{$60 \%$} & 1 & 1.233 & 69252707 & 43.79 & 39470379 & Propane (CAS) \\
\hline & 2 & 1.283 & 88728819 & 56.11 & 40780252 & Butane, 2-methyl- (CAS) \\
\hline & 3 & 1.364 & 162835 & 0.10 & 132889 & Butane, 2-methyl- (CAS) \\
\hline \multirow[t]{3}{*}{$70 \%$} & 1 & 1.262 & 62747061 & 48.72 & 33082575 & Propane (CAS) \\
\hline & 2 & 1.291 & 65955404 & 51.22 & 27147997 & Butane, 2-methyl- (CAS) \\
\hline & 3 & 1.392 & 76032 & 0.06 & 56093 & Butane, 2-methyl- (CAS) \\
\hline \multirow[t]{3}{*}{$80 \%$} & 1 & 1.274 & 55239713 & 47.76 & 32537702 & Propane (CAS) \\
\hline & 2 & 1.302 & 60368672 & 52.20 & 25227005 & Butane, 2-methyl- (CAS) \\
\hline & 3 & 1.403 & 50468 & 0.04 & 36511 & Butane, 2-methyl- (CAS) \\
\hline \multirow[t]{3}{*}{$90 \%$} & 1 & 1.256 & 57343794 & 50.58 & 32724013 & Propane (CAS) \\
\hline & 2 & 1.285 & 55935345 & 49.34 & 24839940 & Butane, 2-methyl- (CAS) \\
\hline & 3 & 1.385 & 97243 & 0.09 & 70756 & Butane, 2-methyl- (CAS) \\
\hline \multirow[t]{3}{*}{$100 \%$} & 1 & 1.256 & 82290810 & 46.62 & 46144635 & Propane (CAS) \\
\hline & 2 & 1.308 & 94130281 & 53.33 & 40277871 & Butane, 2-methyl- (CAS) \\
\hline & 3 & 1.389 & 93813 & 0.05 & 77477 & Butane, 2-methyl- (CAS) \\
\hline
\end{tabular}

